\title{
Influence of plant spacing, training and fertigation on growth, yield and quality of capsicum under naturally ventilated polyhouse
}

\author{
Jasbir Singh, Vicky Singh* and Pardeep Kumar ${ }^{1}$ \\ Krishi Vigyan Kendra, Ferozepur (Punjab) India \\ (Email: j-sandhu@pau.edu; vickysinghpau@gmail.com)
}

\begin{abstract}
Capsicum hybrid Mekong was grown under naturally ventilated polyhouse during summer season of 2012 at Vegetable Research Farm, Department of Vegetable Science and Floriculture, CSKHPKV Palampur, Himachal Pradesh. Planting was done in two rows on $0.9 \mathrm{~m}$ wide bed leaving $60 \mathrm{~cm}$ path between two beds following the spacing of $60 \mathrm{~cm} \times 30 \mathrm{~cm}\left(\mathrm{~S}_{1}\right)$ and $45 \mathrm{~cm} \times 30 \mathrm{~cm}$ $\left(S_{2}\right)$, with double $\left(T_{1}\right)$, three $\left(T_{2}\right)$ and four $\left(T_{3}\right)$ stems and fertilized $\left(F_{1}\right)$ twice a week and $\left(F_{2}\right)$ thrice a week. The data were analyzed statistically following Factorial Randomized Block Design. The result revealed that the plant height, fruit weight, fruit length, fruit breadth, pericarp thickness were significantly more in $\mathrm{S}_{1} \mathrm{~T}_{1} \mathrm{~F}_{2}$ treatment. The number of fruits per plant, fruit yield per plant, yield/ $\mathrm{m}^{2}$ and benefit cost ratio was significantly superior in $\mathrm{S}_{1} \mathrm{~T}_{3} \mathrm{~F}_{2}$ treatment. While there was no significant effect of spacing, training and fertigation levels on days to 50 per cent flowering, days to first harvest, harvest duration and shelf life at room temperature.
\end{abstract}

Key Words : Spacing, Training, Fertigation, Quality growth

View Point Article : Singh, Jasbir, Singh, Vicky and Kumar, Pardeep (2019). Influence of plant spacing, training and fertigation on growth, yield and quality of capsicum under naturally ventilated polyhouse. Internat. J. agric. Sci., 15 (1) : 173-176, DOI:10.15740/HAS/IJAS/15.1/ 173-176. Copyright@2019: Hind Agri-Horticultural Society.

Article History : Received : 17.07.2018; Revised : 18.12.2018; Accepted : 24.12.2018

\footnotetext{
* Author for correspondence:

${ }^{1}$ Department of Vegetable Science and Floriculture, C.S.K. Himachal Pradesh Krishi Vishvavidyalaya, Palampur (H.P.) India
} 